\title{
Impact of air pollution on lung inflammation and the role of Toll-like receptors
}

This article was published in the following Dove Press journal:

International Journal of Interferon, Cytokine and Mediator Research

25 June 2012

Number of times this article has been viewed

\section{Laurel E Plummer \\ Suzette Smiley-Jewell \\ Kent E Pinkerton \\ Center for Health and the Environment, University of California, Davis, CA, USA}

Abstract: The link between air pollution and adverse pulmonary health effects is well established. The National Ambient Air Quality Standards were formulated to protect human health. These standards are strictly enforced based on strong associations between elevated air pollution levels and increased emergency room visits and hospitalizations due to respiratory conditions. Impacts of air pollution on lung health occur due to the direct interaction between the external environment and internal biological systems and processes. The innate immune system is one of the first lines of defense against inhaled air contaminants and is characterized by activation of key signaling pathways and inflammatory cell recruitment to the lung. Numerous independent and often redundant pathways participate in innate and adaptive immune responses Given the impact of air pollution on human health, extensive research efforts have aimed to characterize the mechanisms of response to various air pollutants and evaluate risk factors contributing to individual susceptibility. A significant body of evidence exists to document air pollution-induced alterations in proinflammatory or oxidative signaling molecules. However, the role of specific pathways participating in the propagation of the inflammatory effects remains unclear. One hypothesis for interindividual susceptibility to inhaled air pollutants is that genetic polymorphisms in inflammatory or oxidative stress pathways may contribute to the diverse range of the inflammatory response. Activation of numerous receptors associated with airway cells culminates in the translocation of nuclear factor-kappa B and other transcription factors to the nucleus, and therefore initiation of altered signaling of proinflammatory mediators. Alterations in the transcription and expression of inflammatory mediators following exposure to air pollution are well documented. However, the interaction between specific air pollutants and specific cell surface and intracellular receptors has not been clearly defined. Involvement of specific pathways in the innate immune response may be dependent on differential physical and chemical characteristics of air pollution. One pathway implicated in the response to inhaled air pollutants is initiated by the activation of Toll-like receptors (TLRs). TLRs and downstream proinflammatory mediators are well studied for their role in pathogen response, yet gaps in the understanding of TLR response to nonpathogenic agents, such as air pollution, exist. TLRs are associated with inflammation and allergy, and emerging evidence suggests they may also play a role in the response and susceptibility to air pollution. However, the specific component, exogenous or endogenous, responsible for the association between air pollution and TLR activation has yet to be clearly identified. Improved understanding of pulmonary response mechanisms and potential mediators of susceptibility to air pollution, including the role of TLRs, may contribute to a reduction of the health burden of air pollution-induced detriments to lung health. This review provides a background of air pollution, health effects associated with exposure to air pollution, and potential contributors to interindividual variability, with a specific focus on TLRs as potential modulators of the immune response.

Keywords: air pollution, ozone, particulate matter, lung, inflammation, Toll-like receptor, TLR
Correspondence: Kent Pinkerton University of California, Davis,

Center for Health and the Environment. Bldg 3792, Old Davis Road,

Davis, CA 95616, USA

Tel +l 5307528334

Fax +l 5307525300

Email kepinkerton@ucdavis.edu
International Journal of Interferon, Cytokine and Mediator Research 2012:4 43-57

(C) 2012 Plummer et al, publisher and licensee Dove Medical Press Ltd. This is an Open Access article

Dovepress

http://dx.doi.org/10.21 47/IJICMR.S29352 which permits unrestricted noncommercial use, provided the original work is properly cited. 


\section{Introduction}

Considerable epidemiological and toxicological studies have established a clear link between exposure to air pollution and adverse pulmonary health effects. To protect human health, the United States Environmental Protection Agency established the National Ambient Air Quality Standards (NAAQS) to regulate "criteria" air pollutants: ozone $\left(\mathrm{O}_{3}\right)$, particulate matter $(\mathrm{PM})$, nitrogen oxides $\left(\mathrm{NO}_{\mathrm{x}}\right)$, sulfur oxides $\left(\mathrm{SO}_{\mathrm{x}}\right)$, lead, and carbon monoxide $(\mathrm{CO})$. Regulation of these criteria air pollutants through the Clean Air Act (CAA) is based on scientific evidence that exposure to air pollution is associated with the development (long-term effect) or exacerbation (short-term effect) of a variety of respiratory conditions. As required by the CAA, the NAAQS are routinely reevaluated to ensure that they are protective for both healthy and sensitive individuals. Acute and chronic exposure to atmospheric gases and PM are associated with increased emergency room visits and hospital admissions for exacerbations of pulmonary conditions, including asthma and chronic obstructive pulmonary disease (COPD). Since their enactment, the NAAQS designations and subsequent regulation have contributed to reduced air pollution levels for improved public health benefit. However, despite these successful reductions in ambient air pollution, adverse human health effects from these key pollutants may still occur at low levels of exposure. The potential impacts of adverse health effects of low levels of air pollution is of particular concern for susceptible populations, including children, the elderly, and those with preexisting respiratory conditions.

Inhaled pollutants initiate rapid and efficient pulmonary defense mechanisms following interaction with airway cells as part of the evolutionarily conserved innate immune response. These cellular and biochemical defense mechanisms function to prevent excessive tissue damage and are orchestrated through numerous redundant inflammatory and oxidative stress pathways. Inhaled agents, including microbes, allergens, and oxidants or foreign agents, may activate these pathways through receptor- and/or nonreceptor-mediated signaling. Further, these effects may result from direct interaction of air pollutants with various receptors or via interactions with secondary mediators within these inflammatory pathways. Despite convincing evidence that two of the most abundant air pollutants, $\mathrm{O}_{3}$ and $\mathrm{PM}$, contribute to the detriment of lung health, the exact component(s) of air pollution responsible for these effects remains to be elucidated.

For this reason, numerous investigations of air pollution-induced health effects are under way to understand the mechanism behind the inflammatory response to inhaled air pollutants using human, laboratory, and cellular models. Additionally, several studies suggest that the physical and chemical nature of the air pollutant, influenced by many factors including particle size, season and location, ${ }^{1-4}$ contributes to pollutant-specific inflammatory pathways. Due to their role as a target for exogenous and endogenous ligands, Toll-like receptors (TLRs), traditionally known to be activated by pathogens, have been identified as participants in the inflammatory response to noninfectious agents, including air pollution. ${ }^{5}$ However, further investigations into the interactions between TLRs and their various ligands are needed to clarify these relationships. Bauer and colleagues recently summarized evidence for several air pollutants, including $\mathrm{PM}$ and $\mathrm{O}_{3}$, and potential mechanisms for initiation of the inflammatory response. ${ }^{6}$ In summarizing the role of TLRs in air pollution-induced health effects, several themes emerged that further emphasize the potential for pollutantspecific mechanisms governed by direct and/or indirect activation of TLRs through secondary mediators or reactive oxygen species. ${ }^{6}$ Regardless of the precise mechanism of activation, TLR involvement in the response to air pollution represents a potential avenue to improve scientific understanding of adverse pulmonary health impacts. This is especially relevant in considering that variability in TLR expression, whether genetic or a side effect of air pollutant exposure, may contribute to susceptibility and interindividual variability in responses to air pollution and burden of pulmonary diseases. This review begins with a general overview of the pulmonary inflammatory response to inhaled air pollutants, with special emphasis on $\mathrm{O}_{3}$ and $\mathrm{PM}$, and continues with more specific discussion of the potential role of TLRs in these responses.

\section{Ambient air pollution}

The ubiquitous nature of ambient air pollution makes it an important public health concern. It is critical to understand the physical and chemical nature of air pollution in order to interpret and evaluate the adverse pulmonary health outcomes. The potential oxidant potential of air pollution makes it a powerful trigger for pulmonary oxidative stress and inflammation that can initiate responses in the lungs via numerous pathways. Gaseous and particulate components of air pollution arise from a variety of anthropogenic and natural physical and chemical processes, which are classified as either primary or secondary pollutants based on their source of origin. Primary air pollutants are emitted into the atmosphere directly from mobile or stationary sources, such 
as automobiles, factories, and biomass burning. Secondary pollutants are formed through photochemical reactions of primary pollutants in the atmosphere and are not directly emitted. The majority of the criteria pollutants are primary pollutants with the exception of $\mathrm{O}_{3}$, which is a secondary pollutant. $\mathrm{O}_{3}$ is a powerful oxidant that poses a critical risk to lung health when present in the lower atmosphere. Ground-level $\mathrm{O}_{3}$ arises from sunlight-catalyzed reactions between $\mathrm{NO}_{\mathrm{x}}$ and volatile organic compounds (VOCs) emitted from motor vehicle exhaust and industrial emissions. The role of sunlight in this reaction means that peak $\mathrm{O}_{3}$ levels occur during the day and during summertime.

PM can be both directly emitted and formed through the atmospheric physical and chemical transformations of precursor gases, such as VOCs, $\mathrm{SO}_{\mathrm{x}}$, and $\mathrm{NO}_{\mathrm{x}}$. Particle size uniquely impacts deposition patterns within the lung, and therefore, is the basis for the NAAQS size- and massbased regulations. ${ }^{7-9}$ PM is regulated by mass per a given size, with size cutoffs being $\mathrm{PM}_{10}$ (mean mass aerodynamic diameter [MMAD] between $2.5 \mu \mathrm{m}$ and $10 \mu \mathrm{m}$ ) and $\mathrm{PM}_{2.5}(\mathrm{MMAD}<2.5 \mu \mathrm{m})$. Similar to $\mathrm{O}_{3}$, the physical and chemical nature of PM and its complex components make it a potentially robust oxidant and inflammatory agent. $\mathrm{PM}_{10}$ is mechanically generated from crushing, grinding, or abrading of surfaces, such as crustal materials, sea salt, plant and animal debris, tires, and brake pads, followed by suspension into the atmosphere. In agricultural environments, $\mathrm{PM}_{10}$ may become contaminated with microbial components such as fungi or bacteria. ${ }^{10,11} \mathrm{PM}_{2.5}$ arises from fossil fuel and biomass combustion, high-temperature processes, refineries, and atmospheric reactions such as nucleation and condensation of primary gaseous pollutants and atmospheric oxidation of $\mathrm{SO}_{\mathrm{x}}, \mathrm{NO}_{\mathrm{x}}$, and VOCs. ${ }^{12-14}$ Due to the nature of PM generation and atmospheric processing and transformation, redox active components, such as transition metals and organic carbon species, such as polycyclic aromatic hydrocarbons and quinones, comprise or associate with ambient PM as part of the core or adsorbed to the particle surface. ${ }^{15}$ The association between PM and redox-active components is the basis for a hypothesis to explain the ability of PM to induce pulmonary oxidative stress and inflammation. ${ }^{16-19}$

\section{General pulmonary health impacts of air pollution}

Air pollution has been implicated in the development of acute inflammation and respiratory symptoms and the exacerbation of chronic inflammatory conditions, such as asthma and COPD. ${ }^{20}$ Numerous epidemiological studies support associations between respiratory morbidity and exposure to $\mathrm{PM}, \mathrm{O}_{3}$, and other inhalable pollutants and report a range in the severity of impacts from shortness of breath and cough to premature mortality associated with exposure to even low levels of air pollution. ${ }^{21-24}$ Numerous studies investigating the health effects of air pollutants use both clinical, such as changes in lung-function parameters, and subclinical measures, such as alterations in inflammatory mediators, to describe adverse pulmonary impacts.

Many inflammatory mediators are significant players in both cellular and physiological responses to inhaled PM and $\mathrm{O}_{3}$. $\mathrm{O}_{3}$-induced alterations in interleukin (IL)-5, -8 , and granulocyte-macrophage colony-stimulating factor were significantly increased in asthmatics compared to control subjects. ${ }^{25}$ A recent review discussed evidence for the role of specific cytokines and chemokines, including IL-1 ( $\alpha$ and $\beta$ ), IL-6, keratinocyte chemoattractant (mouse homologue for IL-8) and tumor necrosis factor (TNF)- $\alpha$ in both inflammatory and physiologic responses to $\mathrm{O}_{3}$ exposure. ${ }^{26}$ Healthy human subjects exposed to concentrated ambient particles developed pulmonary inflammation characterized by increased presence of inflammatory cells and alterations in IL-8 expression in the lung lavage fluid. ${ }^{27,28}$ Similarly, human subjects exposed to diesel particulates, a major component of ambient PM, developed neutrophilic airway inflammation and increased IL- 8 expression and had altered levels of oxidative stress markers myeloperoxidase and reduced glutathione and urate. ${ }^{29}$ Allen and colleagues measured an association between ambient PM exposure and significant alterations in inflammatory (exhaled NO) and lung-function measurements in children. ${ }^{30}$ Adult exposure to urban London PM for 2 hours was associated with asymptomatic but consistent reductions in lung function (forced expiratory volume in 1 second and forced vital capacity) and increased neutrophilic inflammation that was more pronounced in those with moderate compared to mild asthma. ${ }^{31}$ Exposure to 0.08 -ppm $\mathrm{O}_{3}$ was associated with increased airway inflammation and promotion of antigenpresenting cell phenotypes 18 hours following exposure. ${ }^{32}$ Healthy human subjects exposed to 0.6- $\mathrm{ppm} \mathrm{O}_{3}$, a level below the current 0.8 -ppm standard, had significant $\mathrm{O}_{3}$-induced decreases in lung function and increased neutrophilic inflammation in the airways compared to subjects exposed to clean air. ${ }^{33}$ Other investigators report that atopic individuals, even those without asthma, had enhanced inflammatory responses to inhaled $\mathrm{O}_{3}$ compared to healthy subjects at $\mathrm{O}_{3}$ levels within current NAAQS standards. ${ }^{34,35}$ Taken together, this experimental evidence provides biological plausibility for 
associations between clinical and subclinical manifestations of adverse pulmonary health effects and exposure to ambient air pollutants while providing some indication of potential mechanisms involved.

Symptoms induced by exposure to air pollution, as described above, pose a significant risk to those with preexisting respiratory disease, such as asthma or COPD. Increased or unresolved inflammation or detriments in lung function can have much greater consequences for these individuals as compared to healthy individuals. Asthma and COPD are characterized by chronic pulmonary inflammation but differ in mechanism of development, degree of airway remodeling, and physiological alterations. Asthma is an allergic respiratory disease characterized by airway inflammation and bronchial hyperresponsiveness. Development and exacerbation of asthma symptoms are associated with exposure to air pollution, specifically $\mathrm{O}_{3}$ and $\mathrm{PM}$, and can act as an adjuvant to enhance the inflammatory response. In Southern California's Children's Health Study, adverse impacts on lung function were associated with both $\mathrm{O}_{3}$ and $\mathrm{PM}$ exposure. ${ }^{36}$ Susceptibility to impacts of air pollution later in life may be due to impacts on lung development in utero and throughout childhood that contribute to an asthmatic or susceptible phenotype later in life. ${ }^{37-40}$ Vedal and colleagues demonstrated an increased susceptibility to reductions in peak expiratory flow and increased cough, phlegm production, and sore throat in children with asthma. ${ }^{41}$ Exacerbated responses in asthmatic compared to healthy adult individuals may be related to altered PM-deposition patterns due to altered airway physiology and remodeling, such as hypertrophy of bronchial smooth muscle, transformation of fibroblasts to myofibroblasts, and deposition of subepithelial collagen. ${ }^{42,43}$ This represents a particular concern in environments where bioaerosols may deposit with a greater frequency in those individuals with pathological alterations of the lung.

COPD is a progressive inflammatory condition of the airways, pulmonary vessels, and lung parenchyma, and is characterized by decreased lung function due to airflow obstruction and airway remodeling. ${ }^{44,45}$ Short-term exposure to air pollution is associated with increased hospitalizations in COPD patients, who often are hospitalized due to impaired defense against infection. ${ }^{46-48}$ In contrast to asthma, it remains unclear if long-term exposure to air pollution contributes to the development of COPD; however, associations exist between exacerbations of preexisting COPD due to short-term air pollution exposure. ${ }^{20,45}$ Smoking is a known risk factor for the development of COPD, but not all smokers develop COPD.
This discrepancy may be due to family history and/or genetic polymorphisms that alter patterns of susceptibility. Air pollution may also directly impact inflammatory cells, specifically the alveolar macrophage, or receptors within the lung and their response to infection, which may contribute to aggravating existing diseases. ${ }^{49-51}$

\section{General inflammatory signaling mechanisms and pathways}

While no two air pollutants are physically or chemically identical, oxidative stress and inflammation are two primary mechanisms implicated in pulmonary cell injury and tissue damage following exposure to air pollution in general. The pulmonary response to inhaled pollutants is multidimensional, with several lines of often synergistic and redundant defense mechanisms participating in the maintenance of homeostasis. Pulmonary inflammation is orchestrated through the actions of the innate and adaptive immune systems, which are associated with specific airway cell types. In general, activation of the immune system is initiated and propagated through several well-established pathways that are initiated in response to tissue injury and inflammation or recognition of specific molecular patterns associated with pathogens or host-derived secondary mediators. Although pollutantspecific mechanisms of air pollution-induced inflammation remain unclear, common patterns of immune response include activation of phagocytic cells, clearance of foreign agents, antibody-mediated immunity, cellular influx, and increases in pulmonary epithelial cell permeability. ${ }^{52-54}$ These patterns represent some of the hallmark pathologies of many pulmonary diseases.

Mechanisms of air pollution-induced activation of the inflammatory response have been extensively investigated. As shown in Figure 1, ambient air pollutants contribute to the initiation of the inflammatory response and cytotoxic effects within the lung as a result of direct or indirect impacts of air pollutants on airway and inflammatory cells. Propagation of the inflammatory response occurs through numerous signaling pathways that are mediated by interaction of various exogenous and host-derived ligands with cellsurface or intracellular receptors. Some of the well-known inflammatory response pathways include the arachidonic acid/cyclooxygenase (COX) pathway, the nuclear factor-

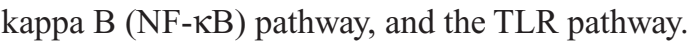

Considering the prominent role of NF- $\kappa \mathrm{B}$ in the pathology of pulmonary disease and what is known about the molecular biology of this transcription factor, it is critical to understand the impacts of air pollution on this central 


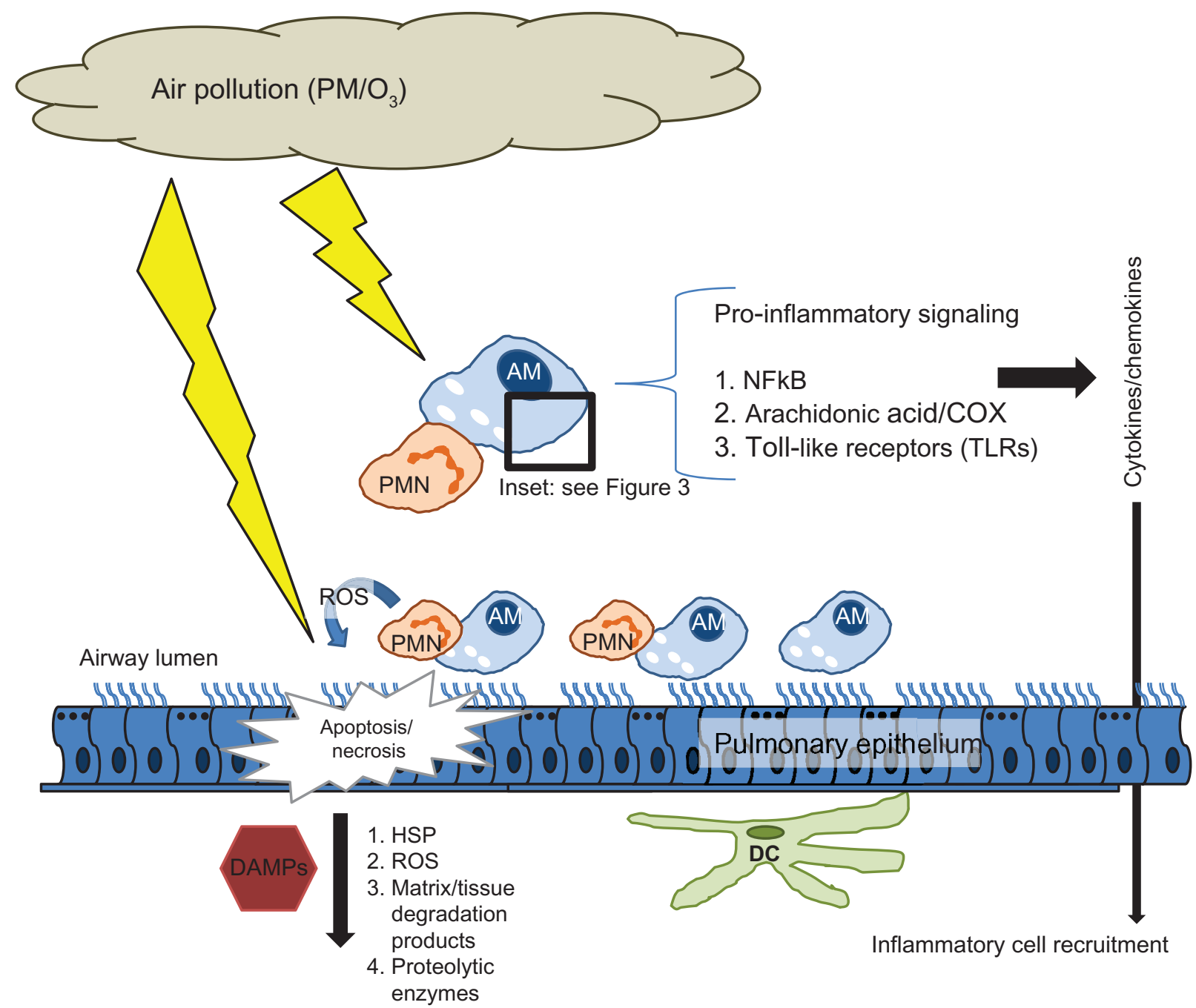

Figure I Pulmonary response to air pollution.

Notes: Toll-like receptor (TLR)-related signaling pathways can be activated by exogenous ligands, both pathogenic and nonpathogenic, as well as endogenous agonists. Nonpathogenic agents, such as air pollution, interact with pulmonary epithelium and airway leukocytes such as alveolar macrophages (AM), neutrophils (PMN), and dendritic cells (DC). Air pollution can directly initiate cell damage and increase oxidant stress to produce downstream activation of inflammatory responses through numerous redundant pathways involving I. nuclear factor kappa B, arachidonic acid/cyclooxygenase, and TLRs (detailed in Figure 3). Additionally, air pollution can indirectly induce inflammatory effects through endogenous agonists for TLRs that are products of tissue injury and repair. Endogenous ligands for TLRs include danger-associated molecular patterns (DAMPs) such as heat-shock proteins (HSP); reactive oxygen species (ROS), tissue matrix breakdown products such as hyaluronan; surfactant protein $A$, and fibrinogen.

inflammatory pathway. ${ }^{55}$ External or internal stimuli, including viral or bacterial infection, free radicals, and cytokines, can trigger the activation of NF- $\mathrm{KB}$ and facilitate its translocation to the nucleus for transcription of additional proinflammatory mediators, including cytokines and chemokines, adhesion molecules, and protein kinases, to further propagate and resolve the insult. ${ }^{56,57}$ Figure 1 details the interaction of air pollutants with airway cells. Activation of NF- $\mathrm{KB}$ and mitogen-activated protein kinases lead to the production of proinflammatory mediators, including IL-1, -6 , and -12 , TNF- $\alpha$, several interferons and nitric oxide. Upregulation of additional mediators involved in propagation and resolution of the inflammatory events, including enzymes associated with tissue and cellular damage, microorganism defense, arachidonic acid metabolites such as prostaglandins, and fibrotic and fibrinolytic processes in response to air pollution, have also been reported. ${ }^{53,58-61}$ In the absence of efficient resolution mechanisms present in individuals with preexisting diseases, these mediators have the potential to damage the pulmonary epithelium and impair host defense, and may ultimately cause further tissue destruction and functional impairment..$^{53}$

\section{Variability in the response to air pollution}

There is clear evidence for increased susceptibility to air pollution-induced health effects in several sensitive subgroups of the population. Harmful effects of air pollution can be modified by an individual's susceptibility relating 
to genetic factors, age, diet, health status, pre-existing health conditions, and socioeconomic status. Variability in response to air pollution may be associated with genetic differences or polymorphisms that convey an increased risk for an individual. ${ }^{62-64}$ Identification of susceptible subgroups of the population who may be particularly vulnerable to air pollution-induced health effects is critical in order to characterize and possibly mitigate potential contributors to interindividual variability and the burden of pulmonary diseases. ${ }^{64}$

Due to the central role of inflammation and oxidative stress in the response to air pollution, genes that modulate inflammation and antioxidant defense mechanisms are considered to contribute to interindividual variability in response to air pollution. ${ }^{33}$ Genetically standardized animal models have been used to identify candidate genes that may convey an increased susceptibility to air pollution-induced health impacts on chromosomes 4, 11, and 17. These studies report correlations between several hallmarks of respiratory health effects, including lung hyperpermeability, injury and inflammation, and genetic differences within these chromosomes. ${ }^{62}$ Some of the candidate genes include those involved with inflammation, including TLR4, TNFA, glutathione peroxidase 1 (GPX1), and xanthine dehydrogenase $(X D H)$; metabolizing enzymes, such as glutathione S-transferase mu 1 (GSTM1), glutathione S-transferase P1 (GSTP1) and nicotimamide adenine dinucleotide phosphate quinine oxidoreductase (NQO1); and other small inducible cytokines, many of which are activated through NF- $\mathrm{KB}$ transcription factor signaling. ${ }^{62,64}$ There is evidence that GSTM1, present in the airways and completely absent in $50 \%$ of the population, may contribute to reduced lung function in deficient individuals. ${ }^{33}$ The deletion of GSTM1 is highly prevalent and is thus the most commonly studied polymorphism, followed by GSTP1. Recently, polymorphisms in a variety of TLR genes have been associated with asthma and atopy in humans and represent a potential target for prevention and therapy for these inflammatory lung diseases. The role of TLR genes in air pollution-induced health effects will be discussed in more detail in a subsequent section of this review.

In addition to genetic factors, age may highly influence pulmonary response to air pollution, with children and the elderly being particularly vulnerable. For example, Halonen and colleagues report increased susceptibility of children ( $<15$ years) to $\mathrm{O}_{3}$-induced asthma exacerbations as well as positive associations between respiratory hospital admissions in the elderly ( $\geq 65$ years old) that were not observed in adults (16-64 years). ${ }^{65}$ Children's sensitivity to adverse pulmonary health effects may be attributed to the developmental stage of the respiratory tract, the immaturity of immune and antioxidant enzyme systems, and the fact that they spend more time outdoors while breathing more air per kilogram of body weight than adults. ${ }^{38,66-68}$ In a group of elderly individuals, both $\mathrm{PM}$ and $\mathrm{O}_{3}$ were correlated with hospital admissions for respiratory conditions for individuals aged 70-79 years. ${ }^{69}$ Further, a recent meta-analysis of previously conducted studies confirmed significant associations between short-term $\mathrm{O}_{3}$ exposure and respiratory hospitalizations, with the strongest association during the summer months and for elderly populations. ${ }^{70}$

Socioeconomic factors may play a secondary role in interindividual variability in adverse pulmonary health outcomes. Strong evidence suggests a disproportionate risk among minority and lower-income communities, which is compounded by low socioeconomic status. ${ }^{71-73}$ Miranda et al report that low-income and minority communities tend to experience higher ambient pollution levels, placing children or the elderly residing in these highly impacted communities at an even greater risk of developing or exacerbating respiratory conditions. ${ }^{74}$ For example, Cakmak et al reported that individuals who did not complete primary school had an increased risk of mortality due to air pollution exposure compared to those with a university education. ${ }^{75}$ This increased risk was further increased in the elderly who did not complete primary school.

\section{Air pollution and Toll-like receptors (TLRs)}

The participation of TLRs in the response to air pollution is of interest because of their documented role in the inflammatory response, including allergy and atopy. Given the close interaction between the external environment and the lung, TLRs have been implicated in lung-associated immune responses, including airway hyperresponsiveness (AHR) and allergic asthma. ${ }^{76}$ Further, TLRs and their identified and potential ligands and downstream mediators may play a role in the response and susceptibility to air pollution-induced pulmonary effects. The role of TLRs in pulmonary disease has been investigated largely by comparing disease incidence among people with and without certain identified genetic polymorphisms. ${ }^{77}$ Dysfunction and unregulated activation of the TLR pathway can contribute to decreased lung function and the pathogenesis of acute and chronic lung inflammatory diseases, including asthma, COPD, and cystic fibrosis..$^{78,79}$ Deletions and/or mutations in TLRs or critical 
proteins within the TLR pathway may contribute both to underlying pathology and either exacerbation or protection from TLR-mediated effects. Therefore, the remainder of this review focuses on the role of this signaling pathway in eliciting and propagating the inflammatory response, as well as the potential role of genetic variability in modification of responses to air pollution and their associations with disease.

\section{TLR structure and function}

TLRs are evolutionarily conserved receptors involved in innate and adaptive immune responses. In general, TLRs alert the pulmonary system to the presence of foreign agents in order to mount a concerted response and ultimate removal of the agent. ${ }^{80}$ TLRs not only orchestrate a rapid and robust response to pathogens or foreign agents to maintain homeostasis in response to inhaled agents, but also play a role in the development or exacerbation of respiratory diseases such as allergic asthma. ${ }^{81}$ TLRs are one of many pattern recognition receptors that facilitate recognition of pathogenassociated molecular patterns (PAMPs) and endogenous danger-associated molecular patterns (DAMPs) to provide a targeted response to a variety of exogenous and endogenous host-derived agents (Table 1). In response to TLR activation, resident and recruited pulmonary monocytes, macrophages, neutrophils, epithelial and endothelial cells, and dendritic cells act as surveyors of the pulmonary environment in order to efficiently respond to a foreign agent. Of these cell types, antigen-presenting cells such as macrophages and dendritic cells may be particularly important participants in host defense as it relates to the role of TLRs in the adaptive immune response. ${ }^{82}$ TLRs recognize PAMP, which due to their critical role in the biological function of the pathogens are not subject to high mutation rates. ${ }^{83}$ The signaling pathways for TLR and general inflammatory insults are similar in their utilization of the translocation of NF- $\mathrm{KB}$ to the nucleus and subsequent release of proinflammatory cytokines and chemokines. Therefore, the potential for synergistic interaction in the propagation of the inflammatory response exists.

Several recent reviews discuss TLR pathway activation and signaling in detail. ${ }^{6,81,84,85}$ As shown in Table 1, TLRs are found on the surface of a multitude of cells (TLR1-6, 10) and intracellularly within endosomes (TLR3, 7/8, 9). ${ }^{85}$ TLR structure, detailed in Figure 2, is characterized by an amino-terminal extracellular leucine-rich repeat domain and an intracellular Toll/IL-1 receptor (TIR) responsible for ligand binding and signal transduction, respectively. ${ }^{80}$ The TLR family of receptors are type 1 integral membrane glycoproteins with structural homology in the cytoplasmic region to the larger superfamily of IL-1 receptors. ${ }^{84}$ TLR activation, shown in Figure 3, can occur via two pathways: (1) the myeloid differentiation primary-response protein 88 (MyD88)-dependent pathway, and (2) the MyD88independent pathway. These two pathways correspond to early and late-phase NF- $\mathrm{KB}$ signaling and pathway-specific induction of proinflammatory cytokines and chemokines or interferon signaling. ${ }^{84}$ With the exception of TLR3, the majority of TLRs activate the MyD88-dependent pathway. Briefly, the MyD88 pathway begins with ligand binding to TLRs at the cell or endosomal surface that initiates proteinprotein interactions at the intracellular TIR domain activating adapter protein MyD88, which promotes association with IL-1 receptor-associated kinases (IRAK) 1 and 4. TNF-associated factor 6 is recruited to IRAK-1, followed

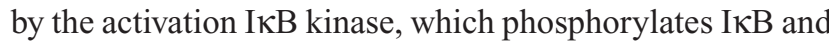
leads to activation of mitogen-activated protein kinase and, ultimately, the release and translocation of NF- $\kappa B$ into the nucleus. NF- $\kappa \mathrm{B}$ activation induces transcription of proinflammatory cytokines TNF- $\alpha$, IL-1 $\beta$, IL-6, IL-8, IL-12, and keratinocyte chemoattractant. ${ }^{79,86}$ An intermediate MyD88dependent pathway requires additional adaptor molecules, such as MyD88 adaptor-like TIR domain-containing adaptor protein. The MyD88-independent pathway utilizes adaptor protein TIR-domain-containing adapter-inducing interferon- $\beta$ (TRIF), TRIF-related adaptor molecule to signal transforming growth factor beta-activated kinasebinding kinase 1 and retinoic acid-inducible protein, and, finally, transcription factors interferon regulatory factor 3 and 7. These two transcription factors induce upregulation of effector molecules and interferon (IFN)-inducible genes, such as IFN-gamma-induced protein 1 and IFN- $\beta$. $^{81,84,87}$

TLR signaling can be initiated through the interaction of numerous exogenous and endogenous ligands specific to a wide variety of TLRs. As detailed in Table 1, exogenous ligands include viruses and cell wall components of Grampositive and Gram-negative bacteria such as bacterial endotoxin/lipopolysaccharide, a well known inflammatory agent. PM in particular represents an avenue for introduction of TLR-activating allergens and microbes into the lungs and presents a particular concern for those with preexisting respiratory conditions that prevent efficient clearance of these agents from the lungs. Numerous reports indicate that respirable dusts, ie, $\mathrm{PM}_{10}$, are often associated with pathogenic components or bioaerosols containing microorganisms and microbial components. ${ }^{88-91}$ Respiratory symptoms in response to inhaled bioaerosols present in 
Table I Toll-like receptors and associated ligands

\begin{tabular}{|c|c|c|c|c|}
\hline TLR \# & $\begin{array}{l}\text { Prominent } \\
\text { cell type }\end{array}$ & $\begin{array}{l}\text { Associated } \\
\text { lung disease }\end{array}$ & Ligands & Source/description \\
\hline \multirow[t]{8}{*}{ I } & Multiple & Asthma & Lipoproteins (triacyl lipopeptides) & Bacteria \\
\hline & & & soluble factors & \\
\hline & & & Lipoproteins, peptidoglycans, & Gram-positive bacteria cell wall components \\
\hline & & & lipoteichoic acid & \\
\hline & & & Lipoarabinomannan, & Mycobacterial cell-wall components \\
\hline & & & Mycolylarabinogalactan, lymosan (yeast) & \\
\hline & & & Phenol-soluble modulin & Anti-microbial \\
\hline & & & Glycoinositolphospholipids & Cell surface membrane component \\
\hline \multirow[t]{5}{*}{2} & AM, myeloid DC & Asthma & Glycolipids & Cell surface membrane component \\
\hline & & & Porins & $\begin{array}{l}\text { Cell surface membrane component } \\
\text { (gram-positive) }\end{array}$ \\
\hline & & & Atypical lipopolysaccharide & Cell wall of gram-negative bacteria \\
\hline & & & Necrotic cells & Induced by air pollution and endogenous media \\
\hline & & & Heat-shock protein $70 *$ & Host \\
\hline \multirow[t]{8}{*}{3} & AM, myeloid DC & & dsRNA & Viruses (ie, West Nile virus) \\
\hline & & & LPS & Cell wall of gram-negative bacteria \\
\hline & & & Taxol & Plant-derived anti-cancer agent \\
\hline & & & Fusion protein & Cancer \\
\hline & & & Envelope protein & Viruses \\
\hline & & & Heat-shock protein $60 *$ & Host; DAMP \\
\hline & & & Heat-shock protein $70 *$ & Host; DAMP \\
\hline & & & Fibrinogen* & Host; DAMP, present in circulation \\
\hline \multirow[t]{12}{*}{4} & AM, myeloid DC & Pneumonia, & Surfactant protein A & Host; DAMP, pulmonary surfactant \\
\hline & & asthma, COPD & Fibronectin* & Host; DAMP, degradation product \\
\hline & & & & of macromol \\
\hline & & & Oligosaccharides of hyaluronic acid* & Host; DAMP, degradation product \\
\hline & & & & of extracellu \\
\hline & & & High mobility group box I & Host; DAMP, degradation product \\
\hline & & & protein $(\mathrm{HMGBI})$ & of macromol \\
\hline & & & Polysaccharide fragments of heparan & Host; DAMP, degradation product \\
\hline & & & sulphate* & of macromol \\
\hline & & & B-defensin 2 & Host; DAMP, antimicrobial molecules \\
\hline & & & Uric acid, adensine triphosphate (ATP) & Host; DAMP \\
\hline & & & ROS & Host; DAMP, antimicrobial molecules \\
\hline \multirow[t]{2}{*}{5} & AM & Pneumonia & Flagellin & Bacteria \\
\hline & & & Diacyl lipopeptides & Mycoplasma \\
\hline \multirow[t]{4}{*}{6} & AM & Asthma & Lipoteichoic acid & Gram-positive bacteria cell wall components \\
\hline & & & Zymosan & Mycobacterial cell-wall component \\
\hline & & & Single-stranded RNA & Viruses \\
\hline & & & Imidazoquinolines & Anti-viral derivatives \\
\hline \multirow[t]{3}{*}{7} & Plasmacytoid DC & Asthma & Loxoribine & Anti-cancer agent \\
\hline & & & Bropirimine & Anti-viral and anti-cancer agent \\
\hline & & & Single-stranded RNA & Viruses \\
\hline 8 & Plasmacytoid DC & Asthma & Imidazoquinolines & Anti-viral and anti-allergic \\
\hline \multirow[t]{2}{*}{9} & Plasmacytoid, & Asthma & non methylated CpG DNA & Bacteria and viruses \\
\hline & myeloid DC & & & \\
\hline 10 & Plasmacytoid DC, B cells & Asthma & ND & ND \\
\hline II & $\mathrm{AM}, \mathrm{DC}$ & & Uropathogenic bacteria & E. coli \\
\hline
\end{tabular}

Note: *May be complicated by biological contamination.

Adapted from Beg, ${ }^{82}$ Akira and Takeda, ${ }^{84}$ Tsan and Gao, ${ }^{5}$ Chaudhuri et al, ${ }^{86}$ Kovach and Standiford ${ }^{85}$

Abbreviations: AM, alveolar macrophages; DC, dendritic cells; DAMP, danger-associated molecular pattern; ND, not determined.

numerous occupational environments including swine confinement houses, poultry farms, and during hay handling have been reported. ${ }^{92}$ Mechanistic studies have confirmed the presence of microbial components on PM samples and their ability to produce TLR-mediated signaling. ${ }^{93}$ These studies demonstrate significant enhancement of the biological response to inactive PM with the addition of low levels of bacterial contamination. While this represents activation of TLR by a known ligand, it is likely that a different mechanism governs TLR involvement in the response to $\mathrm{O}_{3}$. 


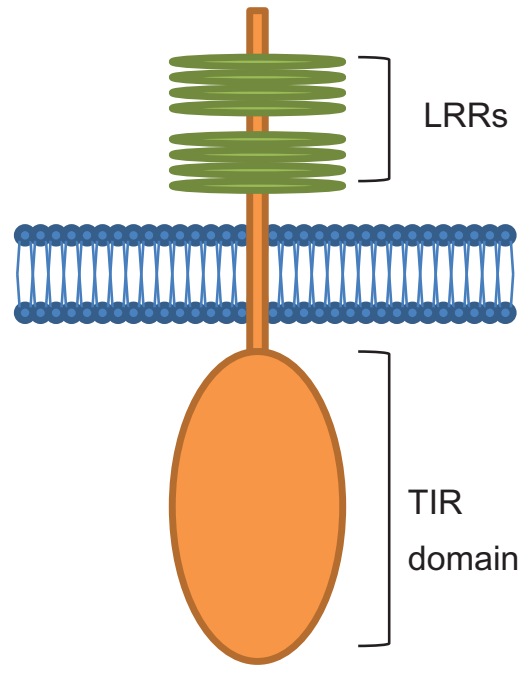

Figure 2 TLR structure.

Notes: Toll-like receptors (TLRs) have three highly homologous regions in the Toll/interleukin-IR (TIR) domain, known as boxes I, 2, and 3. TLRs have tandem repeats of leucine-rich regions (LRRs). Dimerization of these TLR monomers can be between two identical isoforms (homodimerization) or two different isoforms (heterodimerization) which may activate different downstream signaling pathways.
Recent mechanistic studies suggest that $\mathrm{O}_{3}$-induced signaling involves TLR2 and TLR4 activation and culminates in the upregulation of numerous downstream effector molecules, such as increased MyD88 and heat-shock protein $70 .^{87,94}$ However, the gaseous nature of $\mathrm{O}_{3}$ means that an alternate mechanism is likely responsible for TLR involvement in $\mathrm{O}_{3}$-induced inflammation. Although TLR2 and TLR4 have been studied as noted in the aforementioned studies, future research is needed to define the role of the remaining TLRs (TLR1, TLR3, TLR5-12) in air pollution-induced injury and disease.

One such mechanism may involve the potential activation of TLR-related signaling pathways by endogenous TLR agonists. Many endogenous, host-derived agonists are products of tissue injury and repair, which if not removed can contribute to further inflammation. ${ }^{95}$ Many of these ligands have documented associations with exposure to ambient air pollutants including $\mathrm{PM}$ and $\mathrm{O}_{3}$ to their potent oxidant properties. Endogenous ligands for TLR include

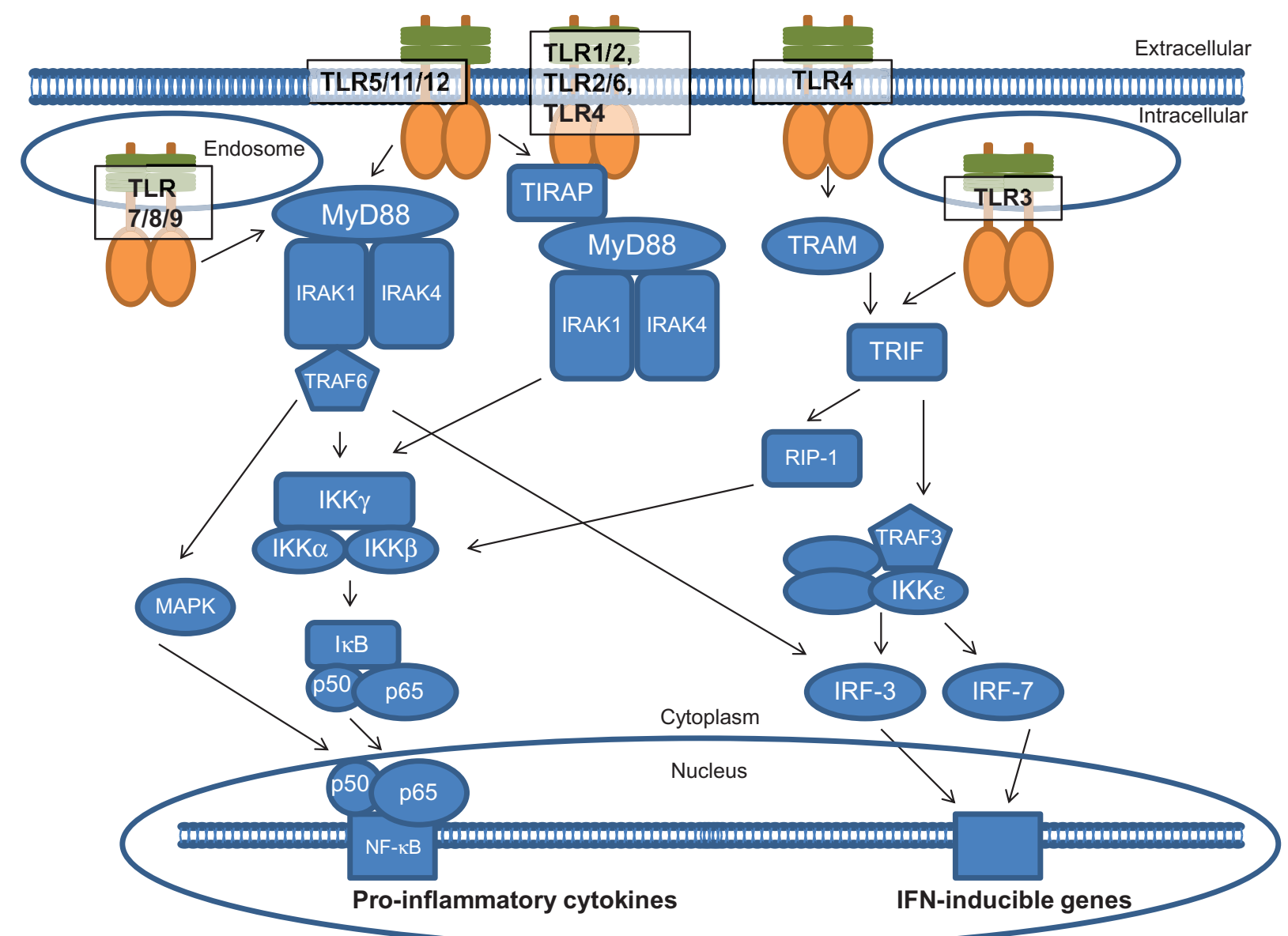

Figure 3 TLR signaling pathways.

Notes: Toll-like receptors (TLRs) are present both on the cell surface and intracellularly within endosomes. Downstream production of proinflammatory cytokines or interferon (IFN)-inducible genes is achieved through MyD88-dependent or independent signaling. Both cell surface and intracellular isoforms signal through MyD88dependent or independent pathways. Cell surface isoforms include TLRI, 2, 4, 5, 6, II, and I2. Intracellular isoforms include TLR3, 7, 8, and 9. Each pathway involves adaptor proteins, kinases, and transciption factors as detailed in the text. 
DAMPs, such as heat shock proteins (HSPs); antimicrobial molecules, such as defensins and reactive oxygen species; proteins released during apoptosis or necrosis; other tissue matrix breakdown products, such as hyaluronan; surfactant protein A; and fibrinogen. ${ }^{86,96}$ Uric acid and adenosine triphosphate may also contribute to the inflammatory response, with adenosine triphosphate having the added potential for participating in a variety of alterations associated with allergic asthma. ${ }^{96}$

As mentioned above, many endogenous agonists, specifically HSP, are also reported to be upregulated following inhalation of air pollution. These reports are critical in understanding the complementary roles of the redundant pathways involved in the response to insult or injury within the lung. Using a genetically modified HSP knockout (KO) mouse strain exposed to $\mathrm{O}_{3}$, investigators concluded that HSP70 played a critical role as an effector molecule downstream of TLR4-derived pulmonary inflammation based on evaluation of inflammatory cell recruitment and increases in protein in the bronchoalveolar lavage fluid. ${ }^{87} \mathrm{O}_{3}$ has also been documented to induce apoptosis and cytotoxicity as well as the production of reactive oxygen species and HSP in human alveolar epithelial cells. ${ }^{97}$ PM has been shown to upregulate HSPs both in vivo and in lung epithelial cells. ${ }^{3,5,98}$ It is important to note that further research into the role of endogenous ligands is needed, as potential microbial contamination is often a concern, and the precise role of these ligands is an active area of research. ${ }^{5,82,99}$

Numerous in vivo studies support a role for TLR in air pollution-induced inflammation and have used genetically modified mice with TLR KO or point mutations to establish its role in the inflammatory response. One study investigated the role of TLR4 in the physiologic and biologic response to lipopolysaccharide, $\mathrm{O}_{3}$, and residual oil fly ash, a PM surrogate. ${ }^{100}$ Investigators found differing involvement of TLRs depending, on the nature of the exposure, supporting the concept that different pollutants have unique mechanisms for the involvement of TLR. Specifically, subchronic but not acute exposure to $\mathrm{O}_{3}$ was TLRdependent and airway physiology was significantly altered in the absence of a significant impact on the neutrophilic inflammatory response. Hollingsworth and colleagues also confirmed that $\mathrm{O}_{3}$-induced AHR was TLR-dependent since it was absent in TLR4 KO mice, despite the presence of neutrophilic inflammation. ${ }^{101}$ Similarly, TLR4 and pulmonary hyperpermeability were differentially expressed in $\mathrm{O}_{3}$-susceptible mice compared to $\mathrm{O}_{3}$-resistant mice. ${ }^{102}$ Another study demonstrated that expected inflammatory responses were attenuated in the absence of TLR2 or 4, suggesting a health-protective benefit of TLR. ${ }^{103}$ Authors concluded that adaptor protein MyD88 was critical in the development of $\mathrm{O}_{3}$-induced AHR, neutrophil recruitment and cytokine and chemokine induction. Following exposure to diesel particulates, $\mathrm{C} 3 \mathrm{H} / \mathrm{HeJ}$ mice with a TLR4 point mutation had significantly fewer neutrophils in bronchoalveolar lavage and lower expression of MIP-1 compared to control $(\mathrm{C} 3 \mathrm{H} / \mathrm{HeN})$ mice. ${ }^{104}$ Given the evidence for TLR participation in air pollution-induced pulmonary responses, further mechanistic studies are warranted with consideration for TLR structure, function, and potential ligands.

\section{TLR and interindividual variability in disease susceptibility}

TLR is clearly involved in numerous inflammatory diseases such as asthma, sepsis, and atheroscelerosis, many of which are further impacted by exposure to air pollutants. ${ }^{37,105,106}$ Recently, the role of TLR has expanded from being solely associated with inflammation to include allergy and atopy. ${ }^{107}$ Contributions of both environmental impacts and genetic variability on TLR expression and function are two potential avenues leading to considerable variability in individual susceptibility to ambient air pollution-induced health impacts.

Exposure to ambient air pollution may modulate the expression of pulmonary TLRs, thus increasing an individual's susceptibility to adverse pulmonary health impacts due to a blunted ability to respond to a subsequent insult or microbial event. The risk of additional pulmonary impacts resulting from air pollution may present further concern for individuals with pulmonary infections. Modulation of TLRs in response to environmental tobacco smoke, comprised of combustion-generated gases and particulates, has been reported. TLR2, known to recognize mycobacterial components, has decreased expression in the lungs of smokers, indicating that the immune response to tuberculosis-like organisms may be suboptimal following repeated exposure to tobacco smoke. ${ }^{108}$ Similarly, von Scheele and colleagues reported tobacco smoke-induced differences in regulation of TLR2 in two groups of smokers with COPD compared to nonsmokers. ${ }^{109}$ Taken together, these reports suggest that chronic exposure to high levels of an inhaled pollutant, such as that resulting from fossil fuel and biomass combustion, 
may impact the lung by reducing its ability to respond to additional infection. Further research is needed to evaluate this hypothesis in the context of exposure to inhaled air pollution.

Genetic polymorphisms may contribute to interindividual variability in the susceptibility to air pollution-induced inflammatory lung diseases. The impact of TLR dysfunction resulting from genetic polymorphisms has implications for an altered innate immune response and an increased susceptibility and predisposition to infections. Dysfunction or absence of important molecules within inflammatory signaling pathways may lead to decreased signaling in response to TLR agonists and may ultimately impact innate and adaptive immune responses. ${ }^{110}$ However, as discussed previously, dysfunction in the TLR pathway may also have health-protective potential. In a recent study of asthmatics, two consistent genotypic differences in TLR4 and CD14 were significantly less frequent in asthmatics compared to healthy individuals, suggesting that these polymorphisms may be health protective. ${ }^{111}$

As shown in Table 1, incidences of inflammatory diseases are influenced by polymorphisms in several TLRs, including 2, 7, 8, 9, and 10. Kormann and colleagues reported associations between TLR polymorphisms in TLRs 1,2 , and 6 and asthma development in children living in urban locations. ${ }^{12}$ Several birth cohort studies from the Netherlands report a significant association between TLR polymorphisms that may result from TLR2 participation in Treg-cell signaling. Treg signaling is important in balancing immune responses to maintain or acquire tolerance against allergies. ${ }^{113}$ The mechanisms behind the role of TLR in asthma may be explained by the decreased activity of allergen-specific Treg cells and the reduced production of Th1 cytokines traditionally signaled by TLR $4 .{ }^{110}$ Childhood asthma was significantly influenced by two TLR2 and four TLR4 polymorphisms in a cohort of children exposed to traffic-related air pollution including $\mathrm{PM}$ and $\mathrm{NO}_{\mathrm{x}}{ }^{114}$ TLR7, 8, and 9 have also been associated with allergy and asthma; however, contrasting results are indicative of the need for further study. ${ }^{115,116}$ The importance of TLR7 and 8 is supported by recent studies that demonstrate effective suppression of experimental asthma through induction of type 1 interferons. ${ }^{117}$ Taken together, there is strong evidence that TLRs play a significant role in the modulation of the innate and adaptive immune responses.

In addition to TLR polymorphisms, genetic variability in transcription factors involved in the TLR pathway may also play a role in susceptibility to respiratory disease. For example, Kim et al demonstrated associations between AHR in children and polymorphisms within the IL-10 promoter, which is a critical region for immune-regulation and antiinflammatory responses. ${ }^{118}$ Reijmerink and colleagues identified several single-nucleotide polymorphisms in TLRrelated pathway genes, such as intracellular PAMP receptors, and reported associations between asthmatic phenotypes. ${ }^{119}$ Research continues to identify novel TLR-related genes in the response to established ligands, and further studies using in vivo models and human subjects will elucidate the role of these novel findings in the pathology of pulmonary diseases. ${ }^{120}$

Lastly, while a detailed discussion of epigenetics is outside the scope of this review, recent evidence in a cohort of children suggests that short-term particulate matter exposure was associated with lower iNOS promoter methylation and that common promoter sequence variants in NOS2 significantly affect iNOS methylation. ${ }^{121}$ This evidence is some of the first to show contributions of genetic and epigenetic variations in air pollution-mediated phenotype expression. ${ }^{121}$ These investigators believe that this approach provides a unique tool to identify novel pathways possibly involved in individual susceptibility to ambient air pollution, and there will likely be significant research continuing in this direction.

\section{Conclusion}

An extensive body of literature outlines the strong association between exposure to air pollution and adverse pulmonary health outcomes, especially in susceptible populations. Ambient $\mathrm{O}_{3}$ and $\mathrm{PM}$ are two air pollutants with clear epidemiological associations between exposure and increased incidence of pulmonary inflammation and changes in lung function. A role for involvement of TLR in the development and exacerbation of pulmonary health effects has been documented in numerous epidemiological and toxicological studies. However, pollutant-specific mechanisms appear to be a biologically plausible explanation for the involvement of TLR in response to two pollutants with differing physical and chemical characteristics. Numerous studies have demonstrated a role for TLR as a receptor for both exogenous and host-derived endogenous ligand, derived from cells damaged by oxidants associated with air pollutants. An improved understanding of the nature of TLRs, their ligands, and signal transduction pathways represents a potential target for therapeutic and preventive 
purposes. ${ }^{85}$ Research in this field has novel implications for reducing the overall health burden posed by exposure to air pollution and should be actively pursued.

\section{Acknowledgments}

The background literature research presented in this manuscript has contributed to the conceptual development of original research for inhaled ambient and engineered particles, as funded by US EPA Grants R831714, R832414, R82215, NIOSH Grant 0H07550 and NIEHS Grants RC1 ES018232 and U01 ES020127 to the University of California, Davis. The authors have sole responsibility for the writing and content of the paper. The contents of this review may not necessarily reflect the views of the funding organizations.

\section{Disclosure}

The authors report no conflicts of interest in this work.

\section{References}

1. Becker S, Dailey LA, Soukup JM, Grambow SC, Devlin RB, Huang YC. Seasonal variations in air pollution particle-induced inflammatory mediator release and oxidative stress. Environ Health Perspect. 2005;113(8):1032-1033.

2. Bell ML, Ebisu K, Peng RD, et al. Seasonal and regional short-term effects of fine particles on hospital admissions in 202 US counties, 1999-2005. Am J Epidemiol. 2008;168(11):1301-1310.

3. Farina F, Sancini G, Mantecca P, Gallinotti D, Camatini M, Palestini P. The acute toxic effects of particulate matter in mouse lung are related to size and season of collection. Toxicol Lett. 2011;202(3):209-217.

4. Hetland RB, Cassee FR, Lag M, Refsnes M, Dybing E, Schwarze PE. Cytokine release from alveolar macrophages exposed to ambient particulate matter: heterogeneity in relation to size, city and season. Part Fibre Toxicol. 2005;2:4.

5. Tsan M-F, Gao B. Endogenous ligands of Toll-like receptors. J Leukoc Biol. 2004;76:514-519.

6. Bauer RN, Diaz-Sanchez D, Jaspers I. Effects of air pollutants on innate immunity: the role of Toll-like receptors and nucleotide-binding oligomerization domain-like receptors. J Allergy Clin Immunol. 2012;129(1):14-26.

7. Menache MG, Miller FJ, Raabe OG. Particle inhalability curves for humans and small laboratory animals. Ann Occup Hyg. 1995;39(3): $317-328$.

8. Mendez LB, Gookin G, Phalen RF. Inhaled aerosol particle dosimetry in mice: a review. Inhal Toxicol. 2010;22(12):1032-1037.

9. Stuart BO. Deposition and clearance of inhaled particles. Environ Health Perspect. 1984;55:369-390.

10. Rylander R. Endotoxin and occupational airway disease. Curr Opin Allergy Clin Immunol. 2006;6(1):62-66.

11. Alexis NE, Lay JC, Zeman K, et al. Biological material on inhaled coarse fraction particulate matter activates airway phagocytes in vivo in healthy volunteers. J Allergy Clin Immunol. 2006;117(6): 1396-1403.

12. Wilson WE, Suh HH. Fine particles and coarse particles: concentration relationships relevant to epidemiologic studies. J Air Waste Manag Assoc. 1997;47(12):1238-1249.

13. Chow J, Watson J, Lowenthal D, et al. $\operatorname{PM}(10)$ and $\operatorname{PM}(2.5)$ Compositions in California San Joaquin Valley. Aerosol Sci Technol. 1993;18(2):105-128.
14. Chow JC. Health effects of fine particulate air pollution: lines that connect. J Air Waste Manag Assoc. 2006;56(6):707-708.

15. Vidrio E, Jung H, Anastasio C. Generation of hydroxyl radicals from dissolved transition metals in surrogate lung fluid solutions. Atmos Environ. 2008;42(18):4369-4379.

16. Gurgueira SA, Lawrence J, Coull B, Murthy GGK, Gonzlez-Flecha B. Rapid increases in the steady-state concentration of reactive oxygen species in the lungs and heart after particulate air pollution inhalation. Environ Health Perspect. 2002;110(8):749-755.

17. Huang Y-CT, Li Z, Carter JD, Soukup JM, Schwartz DA, Yang IV. Fine ambient particles induce oxidative stress and metal binding genes in human alveolar macrophages. Am J Respir Cell Mol Biol. 2009;41(5):544-552.

18. Imrich A, Ning YY, Lawrence J, et al. Alveolar macrophage cytokine response to air pollution particles: oxidant mechanisms. Toxicol Appl Pharmacol. 2007;218(3):256-264.

19. Li N, Sioutas C, Cho A, et al. Ultrafine particulate pollutants induce oxidative stress and mitochondrial damage. Environ Health Perspect. 2003;111(4):455-460.

20. Kelly FJ, Fussell JC. Air pollution and airway disease. Clin Exp Allergy. 2011;41(8):1059-1071.

21. Laden F, Neas LM, Dockery DW, Schwartz J. Association of fine particulate matter from different sources with daily mortality in six US cities. Environ Health Perspect. 2000;108(10):941-947.

22. Krewski D, Burnett R, Jerrett M, et al. Mortality and long-term exposure to ambient air pollution: ongoing analyses based on the American Cancer Society cohort. J Toxicol Environ Health Part A. 2005;68(13-14):1093-1109.

23. Pope CA 3rd, Thun MJ, Namboodiri MM, et al. Particulate air pollution as a predictor of mortality in a prospective study of US adults. Am J Respir Crit Care Med. 1995;151(3 Pt 1):669-674.

24. Schwartz J. Short-term fluctuations in air pollution and hospital admissions of the elderly for respiratory disease. Thorax. 1995;50(5): 531-538.

25. Bosson J, Stenfors N, Bucht A, et al. Ozone-induced bronchial epithelial cytokine expression differs between healthy and asthmatic subjects. Clin Expl Allergy. 2003;33(6):777-782.

26. Al-Hegelan M, Tighe RM, Castillo C, Hollingsworth JW. Ambient ozone and pulmonary innate immunity. Immunol Res. 2011;49(1-3): 173-191.

27. Samet JM, Graff D, Berntsen J, Ghio AJ, Huang Y-CT, Devlin RB. A comparison of studies on the effects of controlled exposure to fine, coarse and ultrafine ambient particulate matter from a single location. Inhal Toxicol. 2007;19 Suppl 1:29-32.

28. Ghio AJ, Kim C, Devlin RB. Concentrated ambient air particles induce mild pulmonary inflammation in healthy human volunteers. Am J Respir Crit Care Med. 2000;162(3 Pt 1):981-988.

29. Behndig AF, Mudway IS, Brown JL, et al. Airway antioxidant and inflammatory responses to diesel exhaust exposure in healthy humans. Eur Respir J. 2006;27(2):359-365.

30. Allen RW, Mar T, Koenig J, et al. Changes in lung function and airway inflammation among asthmatic children residing in a woodsmokeimpacted urban area. Inhal Toxicol. 2008; 20(4):423-433.

31. McCreanor J, Cullinan P, Nieuwenhuijsen MJ, et al. Respiratory effects of exposure to diesel traffic in persons with asthma. $N$ Engl J Med. 2007;357:2348-2358.

32. Alexis NE, Lay JC, Hazucha M, et al. Low-level ozone exposure induces airways inflammation and modifies cell surface phenotypes in healthy humans. Inhal Toxicol. 2010;22(7):593-600.

33. Kim CS, Alexis NE, Rappold AG, et al. Lung function and inflammatory responses in healthy young adults exposed to 0.06 ppm ozone for 6.6 hours. Am J Respir Crit Care Med. 2011;183(9): $1215-1221$.

34. Khatri SB, Holguin FC, Ryan PB, Mannino D, Erzurum SC, Teague WG. Association of ambient ozone exposure with airway inflammation and allergy in adults with asthma. JAsthma. 2009;46(8):777-785. 
35. Scannell C, Chen L, Aris RM, et al. Greater ozone-induced inflammatory responses in subjects with asthma. Am J Respir Crit Care Med. 1996; 154(1):24-29.

36. Peters JM, Avol E, Gauderman WJ, et al. A study of twelve southern California communities with differing levels and types of air pollutionII. Effects on pulmonary function. Am J Respir Crit Care Med. 1999; 159(3):768-775.

37. Clark NA, Demers PA, Karr CJ, et al. Effect of early life exposure to air pollution on development of childhood asthma. Environ Health Perspect. 2010;118(2):284-290.

38. Pinkerton KE, Joad JP. Influence of air pollution on respiratory health during perinatal development. Clin Exp Pharmacol Physiol. 2006; 33(3):269-272.

39. Sharkhuu T, Doerfler DL, Krantz QT, Luebke RW, Linak WP, Gilmour MI. Effects of prenatal diesel exhaust inhalation on pulmonary inflammation and development of specific immune responses. Toxicol Lett. 2010; 196(1):12-20.

40. Sharkhuu T, Doerfler DL, Copeland C, Luebke RW, Gilmour MI. Effect of maternal exposure to ozone on reproductive outcome and immune, inflammatory, and allergic responses in the offspring. J Immunotoxicol. 2011;8(2):183-194.

41. Vedal S, Petkau J, White R, Blair J. Acute effects of ambient inhalable particles in asthmatic and nonasthmatic children. Am J Respir Crit Care Med. 1998;157(4):1034-1043.

42. Chalupa DC, Morrow PE, Oberdorster G, Utell MJ, Frampton MW Ultrafine particle deposition in subjects with asthma. Environ Health Perspect. 2004;112(8):879-882.

43. Davies DE, Wicks J, Powell RM, Puddicombe SM, Holgate ST. Airway remodeling in asthma: new insights. J Allergy Clin Immunol. 2003; 111(2):215-225.

44. Baines KJ, Simpson JL, Gibson PG. Innate immune responses are increased in chronic obstructive pulmonary disease. PLoS One. 2011; 6(3):e18426

45. Sunyer J. Urban air pollution and chronic obstructive pulmonary disease: a review. Eur Resp J. 2001;17(5):1024-1033.

46. Zanobetti A, Schwartz J, Gold D. Are there sensitive subgroups for the effects of airborne particles? Environ Health Perspect. 2000;108(9): 841-845.

47. Peacock JL, Anderson HR, Bremner SA, et al. Outdoor air pollution and respiratory health in patients with COPD. Thorax. 2011;66(7):591-596.

48. Arbex MA, de Souza Conceicao GM, Cendon SP, et al. Urban air pollution and chronic obstructive pulmonary disease-related emergency department visits. J Epidemiol Community Health. 2009;63(10): 777-783.

49. Sigaud S, Goldsmith CA, Zhou H, et al. Air pollution particles diminish bacterial clearance in the primed lungs of mice. Toxicol Appl Pharmacol. 2007;223(1):1-9.

50. Zhou HW, Kobzik L. Effect of concentrated ambient particles on macrophage phagocytosis and killing of Streptococcus pneumoniae. Am J Respir Cell Mol Biol. 2007;36(4):460-465.

51. Chauhan AJ, Johnston SL. Air pollution and infection in respiratory illness. Br Med Bull. 2003;68:95-112.

52. Williams MA. Innate immunity and airway inflammation. J Innate Immun. 2010;2(2):95.

53. Koren HS, Devlin RB, Graham DE, et al. Ozone-induced inflammation in the lower airways of human subjects. Am Rev Respir Dis. 1989; 139(2):407-415

54. Karin M, Lawrence T, Nizet V. Innate immunity gone awry: linking microbial infections to chronic inflammation and cancer. Cell. 2006; 124(4):823-835.

55. Christman JW, Sadikot RT, Blackwell TS. The role of nuclear factorkappa B in pulmonary diseases. Chest. 2000;117(5):1482-1487.

56. Calixto JB, Campos MM, Otuki MF, Santos ARS. Anti-inflammatory compounds of plant origin. Part II. Modulation of pro-inflammatory cytokines, chemokines and adhesion molecules. Planta Med. 2004; 70(2):93-103.
57. Haddad JJ. Cytokines and related receptor-mediated signaling pathways. Biochem Biophys Res Commun. 2002;297(4):700-713.

58. Frush S, Li Z, Potts EN, et al. The role of the extracellular matrix protein mindin in airway response to environmental airways injury. Environ Health Perspect. 2011;119(10):1403-1408.

59. Garantziotis S, Li Z, Potts EN, et al. TLR4 is necessary for hyaluronanmediated airway hyperresponsiveness after ozone inhalation. Am J Respir Crit Care Med. 2010;181(7):666-675.

60. Moldoveanu B, Otmishi P, Jani P, et al. Inflammatory mechanisms in the lung. J Inflamm Res. 2009;(2):1-11.

61. Li Z, Potts-Kant EN, Garantziotis S, Foster WM, Hollingsworth JW. Hyaluronan signaling during ozone-induced lung injury requires TLR4, MyD88, and TIRAP. Plos One. 2011;6(11):e27137.

62. Kleeberger SR. Genetic aspects of susceptibility to air pollution. Eur Resp J. 2003;21(Suppl 40):52s-56s.

63. Romieu I, Moreno-Macias H, London SJ. Gene by environment interaction and ambient air pollution. Proc Am Thorac Soc. 2010;7: 116-122.

64. Yang IA, Fong KM, Zimmerman PV, Holgate ST, Holloway JW. Genetic susceptibility to the respiratory effects of air pollution. Thorax. 2008;63(6):555-563.

65. Halonen JI, Lanki T, Tiittanen P, Niemi JV, Loh M, Pekkanen J. Ozone and cause-specific cardiorespiratory morbidity and mortality. J Epidemiol Community Health. 2010;64(9):814-820.

66. Hertz-Picciotto I, Baker RJ, Yap PS, et al. Early childhood lower respiratory illness and air pollution. Environ Health Perspect. 2007; 115(10):1510-1518.

67. Joad JP, Ji CM, Kott KS, Bric JM, Pinkerton KE. In-utero and postnatal effects of sidestream cigaretter-smoke exposure on lung function, hyperresponsiveness and neuroendocrine cells in rats. Toxicol Appl Pharmacol. 1995;132(1):63-71.

68. Bateson TF, Schwartz J. Children's response to air pollutants. J Toxicol Environ Health A. 2008;71(3):238-243.

69. Namdeo A, Tiwary A, Farrow E. Estimation of age-related vulnerability to air pollution: assessment of respiratory health at local scale. Environ Int. 2011;37(5):829-837.

70. Ji M, Cohan DS, Bell ML. A meta-analysis of association between short-term ambient ozone exposure and respiratory hospital admissions. Epidemiology. 2011;22(1):S203.

71. Morello-Frosch R, Pastor M, Sadd J. Environmental justice and Southern California's "riskscape" - the distribution of air toxics exposures and health risks among diverse communities. Urban Aff Rev Thousand Oaks Calif. 2001;36(4):551-578.

72. Morello-Frosch R, Pastor M, Porras C, Sadd J. Environmental justice and regional inequality in southern California: implications for future research. Environ Health Perspec. 2002;110:149-154.

73. Sadd JL, Pastor M, Morello-Frosch R, Scoggins J, Jesdale B. Playing it safe: assessing cumulative impact and social vulnerability through an environmental justice screening method in the South Coast Air Basin, California. Int J Environ Res Public Health. 2011;8(5): 1441-1459.

74. Miranda ML, Edwards SE, Keating MH, Paul CJ. Making the environmental justice grade: the relative burden of air pollution exposure in the United States. Int J Environ Res Public Health. 2011; 8(6):1755-1771.

75. Cakmak S, Dales RE, Rubio MA, Vidal CB. The risk of dying on days of higher air pollution among the socially disadvantaged elderly. Environ Res. 2011;111(3):388-393.

76. Basu S, Fenton MJ. Toll-like receptors: function and roles in lung disease. Am J Physiol Lung Cell Mol Physiol. 2004;286(5): L887-L892.

77. Schwartz DA, Cook DN. Polymorphisms of the toll-like receptors and human disease. Clin Infect Dis. 2005;41:S403-S407.

78. Lafferty EI, Qureshi ST, Schnare M. The role of toll-like receptors in acute and chronic lung inflammation. J Inflamm (Lond) 2010;7:57

79. Jeong E, Lee JY. Intrinsic and extrinsic regulation of innate immune receptors. Yonsei Med J. 2011;52(3):379-392. 
80. Armant MA, Fenton MJ. Toll-like receptors: a family of pattern recognition receptors in mammals. Genome Biol. 2002;3: reviews3011.1-reviews3011.6.

81. Chen K, Xiang Y, Yao X, et al. The active contribution of Toll-like receptors to allergic airway inflammation. Int Immunopharmacol. 2011;11(10):1391-1398.

82. Beg AA. Endogenous ligands of Toll-like receptors: implications for regulating inflammatory and immune responses. Trends Immunol. 2002;23(11):509-512.

83. Aderem A, Ulevitch RJ. Toll-like receptors in the induction of the innate immune response. Nature. 2000;406(6797):782-787.

84. Akira S, Takeda K. Toll-like receptor signalling. Nat Rev Immunol. 2004;4(7):499-511.

85. Kovach MA, Standiford TJ. Toll like receptors in diseases of the lung. Int Immunopharmaco. 2011;11(10):1399-1406.

86. Chaudhuri N, Dower SK, Whyte MKB, Sabroe I. Toll-like receptors and chronic lung disease. Clin Sci. 2005;109:125-133.

87. Bauer AK, Rondini EA, Hummel KA, et al. Identification of candidate genes downstream of TLR4 signaling after ozone exposure in mice: a role for heat-shock protein 70. Environ Health Perspect. 2011;119(8): 1091-1097.

88. Menetrez MY, Foarde KK, Esch RK, et al. An evaluation of indoor and outdoor biological particulate matter. Atmos Environ. 2009;43(34): 5476-5483.

89. Ning Y, Imrich A, Goldsmith C-A, Qin G, Kobzik L. Alveolar macrophage cytokine production in response to air particles in vitro: role of endotoxin. J Toxicol Environ Health A. 2000;59(3): $165-180$

90. Rylander R. Endotoxin in the environment - exposure and effects. J Endotoxin Res. 2002;8(4):241-252.

91. Wegesser TC, Last JA. Mouse lung inflammation after instillation of particulate matter collected from a working dairy barn. Toxicol Appl Pharmacol. 2009;236(3):348-357.

92. Timm M, Madsen AM, Hansen JV, Moesby L, Hansen EW. Assessment of the total inflammatory potential of bioaerosols by using a granulocyte assay. Appl Environ Microbiol. 2009;75(24):7655-7662.

93. Becker S, Fenton MJ, Soukup JM. Involvement of microbial components and Toll-like receptors 2 and 4 in cytokine responses to air pollution particles. Am J Respir Cell Mol Biol. 2002;27(5): 611-618.

94. Williams AS, Leung SY, Nath P, et al. Role of TLR2, TLR4, and MyD88 in murine ozone-induced airway hyperresponsiveness and neutrophilia. J Appl Physiol. 2007;103(4):1189-1195.

95. Jiang DH, Liang JR, Fan J, et al. Regulation of lung injury and repair by Toll-like receptors and hyaluronan. Nat Med. 2005;11(11): 1173-1179.

96. Willart MAM, Lambrecht BN. The danger within: endogenous danger signals, atopy and asthma. Clin Exp Allergy. 2009;39(1):12-19.

97. Kosmider B, Loader JE, Murphy RC, Mason RJ. Apoptosis induced by ozone and oxysterols in human alveolar epithelial cells. Free Radic Biol Med. 2010;48(11):1513-1524.

98. Ramage L. Expression or C-reactive protein and heat-shock protein-70 in the lung epithelial cell line A549, in response to PM10 Exposure. Inhal Toxicol. 2004;16:447-452.

99. Erridge C. Endogenous ligands of TLR2 and TLR4: agonists or assistants? J Leukoc Biol. 2010;87(6):989-999.

100. Hollingsworth JW, Cook DN, Brass DM, et al. The role of toll-like receptor 4 in environmental airway injury in mice. Am J Respir Crit Care Med. 2004;170(2):126-132.

101. Hollingsworth JW, Cook DN, Schwartz DA. Toll-like receptors and airway disease. In: O’Neill LA, Brint E, editors. Toll-like Receptors in Inflammation. Basel: Birkhäuser; 2006.

102. Kleeberger SR, Reddy SP, Zhang L-Y, Cho H-Y, Jedlicka AE. Toll-like receptor 4 mediates ozone-induced murine lung hyperpermeability via inducible nitric oxide synthase. Am J Physiol Lung Cell Mol Physiol. 2001;280:326-333.
103. Williams MA, Porter M, Horton M, et al. Ambient particulate matter directs nonclassic dendritic cell activation and a mixed TH1/TH2-like cytokine response by naive CD4+ T cells. J Allergy Clin Immunol. 2007;119:488-497.

104. Inoue $\mathrm{K}$, Takano $\mathrm{H}$, Yanagisawa $\mathrm{R}$, et al. The role of Toll-like receptor 4 in airway inflammation induced by diesel exhaust particles. Arch Toxicol. 2006;80(5):275-279.

105. Brook RD, Rajagopalan S, Pope CA, et al. Particulate matter air pollution and cardiovascular disease an update to the scientific statement from the American Heart Association. Circulation. 2010; 121(21):2331-2378.

106. Barraza-Villarreal A, Sunyer J, Hernandez-Cadena L, et al. Air pollution, airway inflammation, and lung function in a cohort study of Mexico City schoolchildren. Environ Health Perspect. 2008; 116(6):832-838.

107. Tesse R, Pandey RC, Kabesch M. Genetic variations in toll-like receptor pathway genes influence asthma and atopy. Allergy. 2011;66(3):307-316.

108. Droemann D, Goldmann T, Tiedje T, Zabel P, Dalhoff K, Schaaf B. Toll-like receptor 2 expression is decreased on alveolar macrophages in cigarette smokers and COPD patients. Respir Res. 2005;6:68.

109. von Scheele I, Larsson K, Dahlen B, et al. Toll-like receptor expression in smokers with and without COPD. Respir Med. 2011; 105(8):1222-1230.

110. Cook DN, Pisetsky DS, Schwartz DA. Toll-like receptors in the pathogenesis of human disease. Nat Immunol. 2004;5(10):975-979.

111. Zaborowski T, Wojas-Krawczyk K, Krawczyk P, et al. The effect of CD14 and TLR4 gene polymorphisms on the occurrence of atopic and non-atopic asthma. Adv Clin Exp Med. 2011;20(4):413-421.

112. Kormann MSD, Depner M, Harti D, et al. Toll-like receptor heterodimer variants protect from childhood asthma. J Allergy Clin Immunol. 2008;122(1):86-92.

113. Bottema RWB, Kerkhof M, Reijmerink NE, et al. Gene-gene interaction in regulatory T-cell function in atopy and asthma development in childhood. J Allergy Clin Immunol. 2010;126(2):338-346.

114. Kerkhof M, Postma DS, Brunekreef B, et al. Toll-like receptor 2 and 4 genes influence susceptibility to adverse effects of traffic-related air pollution on childhood asthma. Thorax. 2010;65(8):690-697.

115. Qian X-b, Wu Y, Cao S-y, et al. Association of single nucleotide polymorphisms in the promoter region of the TLR9 gene with childhood atopic asthma. Zhonghua Yi Xue Yi Chuan Xue Za Zhi. 2011;28(2):185-189.

116. Lange NE, Zhou X, Lasky-Su J, et al. Comprehensive genetic assessment of a functional TLR9 promoter polymorphism: no replicable association with asthma or asthma-related phenotypes. BMC Med Genet. 2011;12:26.

117. Xirakia C, Koltsida O, Stavropoulos A, et al. Toll-like receptor 7-triggered immune response in the lung mediates acute and longlasting suppression of experimental asthma. Am J Respir Crit Care Med. 2010;181(11):1207-1216.

118. Kim KW, Lee KE, Hong JY, et al. Involvement of IL-10 gene promoter polymorphisms in the susceptibility for childhood asthma. Lung. 2011;189(5):417-423.

119. Reijmerink NE, Bottema RWB, Kerkhof M, et al. TLR-related pathway analysis: novel gene-gene interactions in the development of asthma and atopy. Allergy. 2010;65(2):199-207.

120. Yang IV, Jiang WW, Rutledge HR, et al. Identification of novel innate immune genes by transcriptional profiling of macrophages stimulated with TLR ligands. Mol Immunol. 2011;48(15-16):1886-1895.

121. Salam MT, Byun HM, Lurmann F, et al. Genetic and epigenetic variations in inducible nitric oxide synthase promoter, particulate pollution, and exhaled nitric oxide levels in children. J Allergy Clin Immunol. 2012;129(1):232-239. 
International Journal of Interferon, Cytokine and Mediator Research

Dovepress

\section{Publish your work in this journal}

The International Journal of Interferon, Cytokine and Mediator tory science to therapeutic indications and clinical studies. The Research is an international, peer-reviewed, open-access, online journal. The focus of the journal is to publish original research, reports, editorials, reviews and commentaries on all aspects of interferon, cytokine and mediators of inflammation from laboramanuscript management system is completely online and includes a very quick and fair peer-review system, which is all easy to use. Visit http://www.dovepress.com/testimonials.php to read real quotes from published authors.

Submit your manuscript here: http://www.dovepress.com/international-journal-of-interferon-cytokine-and-mediator-research-journal 